\title{
ANTHOCYANINS IN WHEAT SEED - A MINI REVIEW
}

\section{MICHAELA HAVRLENTOVÁ ${ }^{1}$, IVANA PŠENÁKOVÁ ${ }^{2}$, ALŽBETA ŽOFAJOVÁ ${ }^{1}$, LUBOMÍR RÜCKSCHLOSS ${ }^{1}$, JÁN KRAIC ${ }^{1,2}$}

\author{
${ }^{I}$ National Agricultural and Food Center, Plant Production Research Institute \\ Pieštany, Bratislavská cesta 122, SK-92168 Pieštany, Slovak Republic \\ (havrlentova@vurv.sk) \\ ${ }^{2}$ Department of Biotechnology, University of SS. Cyril and Methodius, Nám. J. Herdu \\ 2, SK-91701 Trnava, Slovak Republic
}

\begin{abstract}
Improving the micronutrients in food has become an important field of the Second Green Revolution. In recent years, minor bioactive compounds such as polyphenols, pigments and carotenoids, have attracted more and more interest from both researchers and food manufactures as health-promoting and disease-preventing effects in both in vitro and in vivo studies. One of plant pigments, wheat anthocyanins as plant phenolics are increasingly attractive as natural compounds positively affecting consumer's health and condition moreover wheat is staple food source consumed usually daily. For a purple, blue, or red colour of wheat seed are responsible glycosylated cyanidins, delphinidins, malvinidins, pelargonidins, petunidins, and peonidins located in aleurone layer or pericarp, respectively. Other than white seed colour is not natural for common hexaploid wheat but this trait can be introduced from donors by aimed breeding programs. The way of wheat anthocyanins to provide positive effects for consumer's physiology is limited due to their specific occurrence in seed parts usually removed during grain milling practice and lower stability during processing to foods.
\end{abstract}

Key words: phenolics, flavonoid, anthocyanins, wheat grain

\section{Introduction}

Anthocyanins are chemical compounds of plant origin well known as pigments responsible for blue, purple, red, or orange coloration of plant tissues and organs. From the structural point of view anthocyanins are glycosides composed of hydroxyled or methoxyled 2-phenylbenzopyrilium skeleton with hydroxyl and methoxy groups in the B-ring. The structural variation extend bounded sugars (the most frequent are pentoses - xylose, arabinose, rhamnose, fructose and hexoses galactose, glucose), aliphatic, and aromatic acids.

The consequence of molecular variability is more than six hundreds known natural anthocyanins. Six the most frequented are cyanidins, delphinidins, malvinidins, pelargonidins, petunidins, and peonidins (IWASHINA, 2000). Anthocyanins are phenolic phytochemicals classified within flavonoids together with flavonols, flavones, flavanols, flavanones, and isoflavonoids (LIU, 2004).

Their biosynthesis initializes conjugation of malonyl-CoA and $p$-coumaroyl-CoA derived from phenylpropanoid biosynthetic pathway under operation of seven enzymes - chalconsynthase, chalconisomerase, flavanon-3-hydroxylase, flavonoid-3hydroxylase, dihydroflavonol-4-reductase, anthocyanin synthase, and flavonoid-3-Oglucosyltransferase (HOLTON and CORNISH, 1995; SCHIJLEN et al., 2004). 
Anthocyanins are generally specified as bioactive, non basicly-nutritional compounds, responsible for antioxidant and UV/photoprotective functions (RYAN et al., 2001), playing also role in plant reproduction (KONG et al., 2003). Anthocyanins participate in the formation of non-specific disease resistance in plants (TREUTTER, 2006) such as pre-harvest sprouting where the red pigment of red-grained wheat is synthetized through the flavonoid biosynthetic pathway, in which the dihydroflavonol4-reductase gene (DFR) is one of the genes involved in anthocyanin synthesis (BI et al., 2014).

Specific properties make anthocyanins attractive in prophylaxis and therapy (ANONYMUS, 2014) due to their antitumor, cardio- and hepatoprotective, antimutagenic, antiulceral, UV-protective, and other health beneficial effects (KONG et al., 2003; KAY, 2006; PRIOR and WU, 2006; HODGSON and CROFT, 2006). It appears that these phytochemicals are responsible for the reduced risk of various diseases associated with oxidative stress, such as cancer and cardiovascular and neurodegenerative diseases (JACOBS and STEFFEN, 2003). Compared to vitamins C and $\mathrm{E}$ which are absorbed in the upper segments of the intestine, anthocyanins are dietary antioxidants presented in the colon in valuable concentrations (MANACH et al., 2004).

Seeds of cereals are not typical sources of anthocyanins nevertheless blue, red, and purple seeds attract consumers, food producers, and plant breeders (GUO et al., 2012), therefore relevant knowledge has been cumulated also in maize, wheat, barley, oat, and rice as the most important world food sources. Coloured-grain wheat varieties with good genetic stability, excellent stress resistance and high yield are still required (GUO et al., 2012).

\section{Anthocyanins in wheat seeds}

Isolation, identification, and analyses of wheat anthocyanins have begun long time ago. DEDIO et al. (1972) detected cyanidine-3-glucoside and peonidine-3-glucoside (Fig. 1) as the main anthocyanins of pericarp in purple wheat seeds. Cyanidine-3glucoside as the dominant anthocyanin in purple wheat seeds was detected also by HOSSEINIAN et al. (2008) and ABDEL-AAL and HUCL (2003) together with cyanidine-3-galactoside (Fig. 1), peonidine-3-glucoside, and others unidentified ones. As the most frequent anthocyanins in blue wheat seeds were declared delphinidine-3glucoside and delphinidine-3-rutinoside (ABDEL-AAL et al., 2006; Fig. 1), cyanidine-3-glucoside and peonidine-3-glucoside (ABDEL-AAL and HUCL, 2003). The blue wheat seeds contain more anthocyanins in flour then in bran, in comparison with purple seeds (ABDEL-AAL and HUCL, 1999). On the other hand, in Hungarian hard red winter wheat varieties and blue-grained varieties, the anthocyanin content of the grind was 21-157 mg kg-1, while that of the flour was only 5.3-17.4 mg kg (VARGA et al., 2013) so most of the anthocyanin content was in the bran.

HU et al. (2007) detected in the wheat cultivar Hedong Wumai also minor anthocyanins - cyanidine-3-galactoside, pelargonidine-3-glucoside (Fig. 1), peonidine 3-glucoside, and ferulic acid (Fig. 1).

Red-coloured wheat seeds contain incomparably lower content of anthocyanins in comparison with blue and purple ones. Relationships between content of catechins, 
tannins, and red colour of wheat seeds published MIYAMOTO and EVERSON (1958). WINKEL-SHIRLEY (2001) inclined to the opinion that pigmentation causes proanthocyanins (condensed tannins).

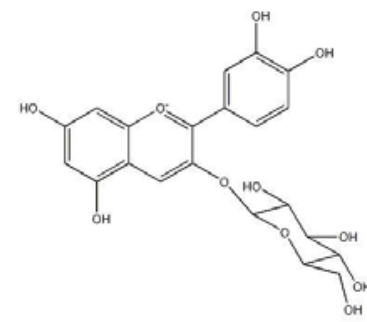

Cyanidine-3-glucoside

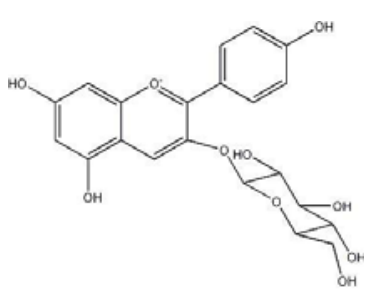

Pelargonidine-3-glucoside

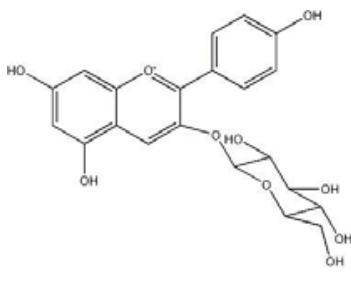

Peonidine-3-glucoside

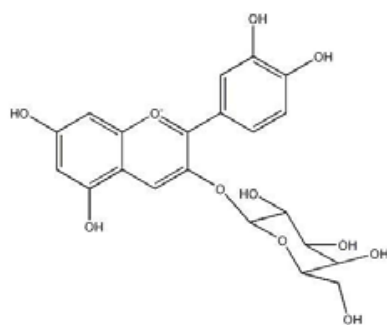

Cyanidine-3-galactoside

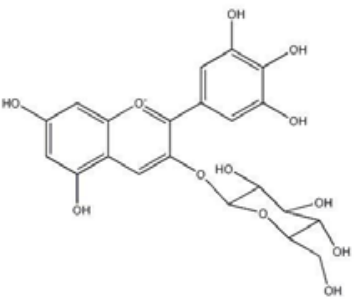

Delphinidine-3-glucoside

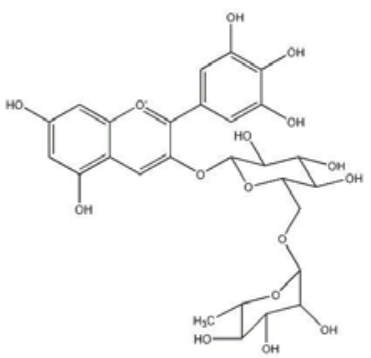

Delphinidine-3-rutinoside

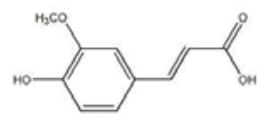

Ferulic acid

Fig. 1. Main anthocyanins of coloured wheat grains.

It is known that environment affects production of polyphenols (ETICHA et al., 2011; KHLESTKINA, 2013) as well as anthocyanins (VARGA et al., 2013) and abiotic stresses like high light intensity, low temperature, high salinity and/or drought stress, and others increase their amounts (CHALKER-SCOTT, 1999). Cold stressed coloured wheat genotypes show either reduced, similar or increased anthocyanin content compared to unstressed plants caused possibly by the allelic state of the $R c$ genes responsible for the seed colour (GORDEEVA et al., 2013). According to authors, the changes in anthocyanin content correlate negatively with the changes of growth parameters in response to cold stress, suggesting the presence of some stressdependent regulation of anthocyanin biosynthesis in wheat coleoptiles.

Changes in anthocyanin content are associated with physiological maturity of the plant and grain, respectively. Location of grains in spike affects anthocyanin content by decreasing at distal positions reflecting positive response to higher source-sink ratio 
(BUSTOS et al., 2012). In the experiments of ŽOFAJOVÁ et al. (2012) genotypes with purple pericarp reached the highest total anthocyanins concentration on the $22^{\text {nd }}$ day post anthesis with increasing and decreasing before and after sampling time, respectively. Pre-anthesis halving increased anthocyanins content by 54 and 37\%, while post-anthesis halving increased this trait by 31 and $29 \%$, respectively (BUSTOS et al., 2012). Promising to increase anthocyanins in purple wheat is the combination of early harvesting and magnesium fertilization (BUSTOS et al., 2012). Content of total phenolic compounds in wheat seeds can be also affected by growing condition (VAHER et al., 2010) or by application of selenium into the soil (CHU et al., 2010).

\section{Origin and genetic control of the seed colour}

The blue and purple colours are not natural for seeds of common wheat. Anthocyanins responsible for blue pigmentation are located in aleurone layer and for purple colour in pericarp, respectively. According to ZEVEN (1991) the blue colour was introduced into wheat from blue coloured diploid wild einkorn wheat Triticum boeoticum, Agropyron tricholphorum, Agropyron glaucum or tall wheatgrass Agropyron elongatum, and purple colour from tetraploid emmer Triticum dicoccum. ZELLER et al. (1991) specified that hexaploid wheat received the blue aleurone colour through chromosomal substitutions of 4A and 4B chromosomes with 4A chromosomes of diploid einkorn wheat Triticum monococcum or Triticum boeticum, respectively. "Black" (deep purple) hues of wheat kernel colour can be due to the combination of anthocyanin genes for blue pericarp and blue aleurone (LI et al., 2005). Results of GUO et al. (2012) showed that the colour inheritance of purplegrained wheat follows a maternal inheritance pattern and that the blue-grained wheat expresses xenia in most cases.

Nevertheless, the genetics of wheat anthocyanins has been unlocking more than fifty years. KNOTT (1958) published that partially dominant gene/genes with different effects were responsible for the blue seed colour. HURD (1959) supported responsibility of two partially dominant genes. Later, KEPPENNE and BAENZIGER (1990) presented that blue colour of wheat aleurone is controlled by single dominant gene. Nowadays, the $B a$ (blue aleurone) gene originated from the $4 \mathrm{E}$ chromosome of Thinopyrum ponticum is considering as the incompletely dominant gene responsible for the blue wheat aleurone (DUBCOVSKY et al., 1996). The concept of single dominant gene has been published recently, too (KNIEVEL et al., 2009). Results on mapping of anthocyanins pigmentation genes in wheat along with the observation of previous studies related were presented by KHLESTKINA et al. (2008). The purple colour of pericarp originated from purple Ethiopian tetraploid and hexaploid wheat and purple Abyssinian wheat (Triticum aethiopicum Jakubz.) was firstly described long ago (WITTMACK, 1906). McINTOSH and BAKER (1967) published hypothesis that the purple colour of wheat pericarp is controlled by two duplicated genes. Two independent responsible genes were located later at the $3 \mathrm{~A}$ and $7 \mathrm{~B}$ chromosomes (PIECH and EVANS, 1979), GRIFFIN (1987) defined these genes as dominantly duplicated. ARBUZOVA et al. (1998) and ARBUZOVA and MAYSTRENKO (2000) located genes for purple seeds in the Triticum aestivum cultivar Purple Feed at 
chromosomes 7B (gene $P p 1$ ) and 6A (Pp2), and in the purple varieties at chromosomes 7B (Pp1) and 2A (Pp3). DOBROVOLSKAYA et al. (2006) located three genes - $P p 1, P p 2$, and $P p 3$ and relabelled at once them as $P p 1$ (at the 7BL chromosome), and $P p 3 b, P p 3 a$ (chromosome 2A). The work of TERESHCHENKO et al. (2012) demonstrated that the D genome of bread wheat Purple carries one of two complementary genes determining purple grain colour and this gene was mapped on the short arm chromosome 7D $2.5 \mathrm{cM}$ distal to the locus $R c-D 1$ determining red coleoptile colour. This position is highly comparable with that of the Ppl gene mapped earlier in tetraploid Triticum durum.

Recently, KNIEVEL et al. (2009) concluded that genetic control of purple coloured wheat pericarp is more complicated and authors also presented design of three dominant alleles. Their results also indicate that wheat breeding programmes aimed to blue seed colour should be feasible, moreover supported by available genetic maps of wheat chromosomes 2A and 7B, mapped genes Pp3 and Pp1, and linked molecular markers (KHLESTKINA et al., 2010; TERESHCHENKO et al., 2012). Red pigmentation of wheat seeds is also based on the content of polyphenols. According to HIMI et al. (2005), expression of four genes (chalkonsynthase, chalkonisomerase, flavanon-3- hydroxylase, and dihydroflavanol-4-reductase) in white coloured wheat seeds was reduced in comparison with red coloured ones. This suggests that three $R$ genes $(R 1, R 2, R 3)$ encoding the seed colour and located at the chromosomes $3 \mathrm{~A}, 3 \mathrm{~B}$, and 3D (McINTOSH et al., 1998; KHLESTKINA et al., 2011) are transcription activators (Myb transcription factors) of genes in flavonoid synthesis (HIMI and NODA, 2005).

\section{Coloured wheat seeds for nutrition}

Coloured wheat seeds are natural source of pigments as phytochemicals and may impart desirables colour and stability for commercial food products (GIUSTI and WROLSTAD, 2003), especially for some slightly alkaline ones (CABRITA et al., 2000). Results of MAZZARACCHIO et al. (2012) indicate a presence of strong interaction between structure of anthocyanins and gluten molecule by playing an important role in pigments adsorption by gluten or its fraction, whereby delphinidine is more adsorbed than cyanidine. Occurrence of anthocyanins in foods and beverages, their transformation during processing, and their bioavailability are described by CLIFFORD (2000). They are beneficial for human health and fitness, possessing several unique traits and functions in organism including anti-obesity effects and influencing of brain activities (PRIOR and WU 2006). Anthocyanins are competent for effective elimination of oxidative stress in human body by balancing between oxidants and antioxidants (TEMPLE, 2000).

Coloured seeds in comparison to colourless equivalent contain higher level of anthocyanins and phenolic compounds and their extracts have stronger antioxidant competence (LIU et al., 2010). This confirmed CHOI et al. (2007) in rice and millet, and LIU et al. (2005) in wheat where purple and blue coloured seeds had higher capability to scavenge free radicals than white ones.

Total amount of anthocyanins in pigmented wheat seeds is relatively high, ABDEL-AAL and HUCL (1999) quantified their amount on average $15.7 \mathrm{mg} \mathrm{kg}^{-1}$ and 
$45.8 \mathrm{mg} \mathrm{kg}^{-1}$ in flour and bran of blue coloured wheat, respectively. On the opposite, IQBAL et al. (2007) detected in extracts from red wheat's bran much lower content of anthocyanins (3.0-3.8 $\left.\mathrm{mg} \mathrm{kg}^{-1}\right)$, nevertheless their occurrence relates to oxygen radical absorbance capacity, radical scavenging activity, and total phenolic content.

There are several specific traits of wheat anthocyanins including the location in seed. Due to occurrence in seed pericarp and aleurone about $80 \%$ of phenolic compounds and flavonoids are in bran or wholemeal (LIU, 2007) and the free radical scavenging capacity of endosperm is much lower (LIYANA-PATHIRANA and SHAHIDI, 2007; SIEBENHANDL et al., 2007). Wheat particle size effect the extraction of phytochemicals. The coarse treatment (unmilled whole bran) exhibit significantly higher antioxidant properties compared to fine treatment, but on the other hand, the fine treatment was higher in anthocyanin content (BREWER et al., 2014).

Common disadvantage of anthocyanins in food processing is the sensitivity to different factors such as temperature (IBANOĞLU, 2002), light intensity, storage conditions, $\mathrm{pH}$, metal ions, enzymes, oxygen, sulphur dioxide, ascorbic acid, sugars, and co-pigments (MAZZA and BROUILLARD, 1987; CABRITA et al., 2000; BA_KOWSKA-BARCZAK, 2005), nevertheless their colour stability can be improved by acylation (BAZKOWSKA-BARCZAK, 2005). The antioxidant capacity can be affected during the thermal processing by both, the extraction solvent and matrix composition (LI et al., 2007).

Analysis of nutrient composition of purple wheat shows that the amount of 40 kinds of nutrients is higher than those of the control (GUO et al., 2012; GUO et al., 2013). For example, the amounts of sodium and manganese in purple wheat are higher than the standards by $312-2018 \%$ and $548-733 \%$, respectively. The contents of beta plus gama-vitamin E were higher by $300 \%$ and zinc, iron, magnesium, and potassium were higher than the control by $100 \%$. In biofortification breeding and functional food development there are also useful significant positive correlations between anthocyanins and molybdenum and glutamic acid concentration observed. On the other hand, significant negative correlations between anthocyanin's concentration and free tryptophan and calcium have been found, too (GUO et al., 2013).

On the opposite, in comparison with other typical anthocyanin sources (e.g. fruits and vegetables) cereals seeds can be stored easily and treated to stable products (ABDEL-AAL et al., 2006). Improvement of anthocyanin content in wheat relates to available genetic resources and breeding programmes. Desirable sources of seed phenolic compounds could be wheat landraces where were also new unique phenolic substances identified (DINELLI et al., 2009). Coloured wheat has been traditionally used like purple hexaploid wheat for special bread baking in the New Zealand. The wheat cultivar Indigo with purple seeds designed for special food products has been released in Austria in the year 2006 (ETICHA et al., 2011). Indigo possess about 200 $\mathrm{mg} \mathrm{kg}^{-1}$ of anthocyanins in grains what is the amount comparable with the red wine. The wheat cultivar PS Karkulka with purple grains has been registered in the year 2014 as results of the breeding program "rainbow wheats" in Slovakia.

More than twenty years running effort in breeding of coloured wheat led to the development of black-grained wheat (BGW) cultivar in China. The BGW possess also high content of proteins, selenium, and amino acids, but has lower bread-making quality (LI et al., 2006). 
The number of registered coloured wheat cultivars is very limited and those available ones have low baking quality and agronomic value (VACULOVÁ et al., 2010).

\section{Conclusions}

Information presented in this mini-review is based on our own experiments as well as published results in topic of wheat anthocyanins. There are both known, the chemical structure of major anthocyanins of the wheat seed as well as their location in specific part of the seed. From the genetic point of view, the final opinion about the number and location of genes is still developing. Different donors of purple, blue, and red colour of the seed have been found and used for incorporation these traits into wheat cultivars. Following challenge for wheat breeders is to create modern wheat cultivars with coloured seeds but also adapted to local growing conditions: materials with accepted agronomic characteristics, technological quality traits, and therefore profitable for producers.

Currently, based on accumulated knowledge also genetic maps and molecular markers linked to relevant loci can effectively support molecular breeding programmes. The interest in creation of new wheat cultivars with seeds coloured by presence of anthocyanins results mainly from their positive effects on health and wellness of the consumer. On the other side, there are also problems to include wheat anthocyanins into food chain due to their unstability during the food processing.

Presented information about wheat anthocyanins can initiate further related challenges e.g. improvement of anthocyanin production in wheat seed, modification of wheat agricultural practice and analyses of environmental influences, redirecting of synthesis or expression of anthocyanin to other seed part that aleurone and pericarp, development of new processing methods more protecting biological properties of anthocyanins.

Acknowledgements: This work was supported by the Operational Programme Research and Development for the project "Systems biology for protection, reproduction and use of plant resources of Slovakia (ITMS 26210120039)" co-financed from the resources of the European Union Fund for Regional Development.

\section{References}

ABDEL-AAL, E.-S.M., YOUNG, J.C., RABALSKI, I.: Anthocyanin composition in black, blue, pink, purple, and red cereal grains. J. Agric. Food Chem., 54, 2006, 4696-4704.

ABDEL-AAL, E.-S.M., HUCL, P.: A rapid method for quantifying total anthocyanins in blue aleurone and purple pericarp wheats. Cereal Chemistry, 76, 1999, 350-354.

ABDEL-AAL, E.-S.M., HUCL, P.: Composition and stability of anthocyanins in bluegrained wheat. J. Agric. Food Chem., 51, 2003, 2174-2180.

ANONYMUS: Biological factors; studies from D. B. M. Ficco and co-authors have provided new information about biological pigments. Life Sci. Weekly, Mar 4, 2014, 1647. 
ARBUZOVA, V.S., MAYSTRENKO, O.I.: Chromosomal location of genes for purple grain colour introgressed in common wheat. Cereal Res. Commun., 28, 2000, 235237.

ARBUZOVA, V.S., MAYSTRENKO, O.I., POPOVA, O.M.: Development of nearisogenic lines of the common wheat cultivar „Saratovskaya 29". Cereal Res. Commun., 26, 1998, 39-46.

BA_KOWSKA-BARCZAK, A.: Acylated anthocyanins as stable, natural food colorants - A review. Pol. J. Food Nutr. Sci., 55, 2005, 107-116.

BI, H.H., SUN, Y.W., XIAO, Y.G., XIA, L.Q.: Characterization of DFR allelic variations and their associations with pre-harvest sprouting resistance in a set of red-grained Chinese wheat germplasm. Euphytica, 195, 2014, 197-207.

BREWER, L.R., KUBOLA, J., SIRIAMORNPUN, S., HERALD, T.J., SHI, Y.-Ch.: Wheat bran particle size influence on phytochemical extractability and antioxidant properties. Food Chem., 152, 2014, 483-490.

BUSTOS, D.V., CALDERINI, D.F., RIEGEL, R.: Anthocyanin content of grains in purple wheat is affected by grain position, assimilate availability and agronomic management. J. Cereal Sci., 55, 2012, 257-264.

CABRITA, L., FOSSEN, T., ANDERSEN, Ø.M.: Colour and stability of the six common anthocyanidin 3-glucosides in aqueous solutions. Food Chem., 68, 2000, 101-107.

CHALKER-SCOTT, L.: Environmental significance of anthocyanins in plant stress responses. Photochem. Photobiol., 70, 1999, 1-9.

CHOI, Y., JEONG, H.-S., LEE, J.: Antioxidant activity of methanolic extracts from some grains consumed in Korea. Food Chem., 103, 2007, 130-138.

CHU, J., YAO, X., ZHANG, Z.: Responses of wheat seedlings to exogenous selenium supply under cold stress. Biol. Trace Elem. Res., 136, 2010, 355-363.

CLIFFORD, M.N.: Anthocyanins - nature, occurrence and dietary burden. J. Sci. Food Agric., 80, 2000, 1063-1072.

DEDIO, W., HILL, R.D., EVANS, L.E.: Anthocyanins in the perikarp and coleoptiles of purple wheat. Can. J. Plant Sci., 52, 1972, 977-980.

DINELli, G., SEGURA CARRETERO, A., DI SILVESTRO, R., MAROTTIA, I., FUB, S., BENEDETTELLI, S., GHISELLI, L., FERNÁNDEZ GUTIÉRREZ, A.: Determination of phenolic compounds in modern and old varieties of durum wheat using liquid chromatography coupled with time-of-flight mass spectrometry. J. Chromatogr. A, 1216, 2009, 7229-7240.

DOBROVOLSKAYA, O., ARBUZOVA, V.S., LOHWASSER, U., RÖDER, M.S., BÖRNER, A.: Microsatellite mapping of complementary genes for purple grain colour in bread wheat (Triticum aestivum L.). Euphytica, 150, 2006, 355-364.

DUBCOVSKY, J., LUO, M.-C., ZHONG, G.-Y., BRANSTEITTER, R., DESAI, A., KILIAN, A., KLEINHOFS, A., DVORAK, J.: Genetic map of diploid wheat, Triticum monococcum L., and its comparison with maps of Hordeum vulgare L. Genetics, 143, 1996, 983-999.

ETICHA, F., GRAUSGRUBER, H., SIEBENHANDL-EHN, S., BERGHOFER, E.: Some agronomic and chemical traits of blue aleurone and purple pericarp wheat (Triticum L.). J. Agric. Sci. Technol., B1, 2011, 48-58. 
GIUSTI, M.M., WROLSTAD, R.E.: Acylated anthocyanins from edible sources and their applications in food systems. Biochemical Engineering J., 14, 2003, 217-225.

GORDEEVA, E.I., SHOEVA, O.Y., KHLESTKINA, E.K.: Cold stress response of wheat genotypes having different $R c$ alleles. Cereal Res. Commun., 41, 2013, 519526.

GRIFFIN, W. B.: Out-crossing in New Zealand wheat measured by occurrence of purple grain. New Zealand J. Agric. Res., 30, 1987, 287-290.

GUO, Z., XU, P., ZHANG, Z., GUO, Y.: Segregation ratios of colored grains in $F_{1}$ hybrid wheat. Crop Breed. Appl. Biot., 12, 2012, 126-131.

GUO, Z.F., ZHANG, Z.B., XU, P., GUO, Y.N.: Analysis of nutrient composition of purple wheat. Cereal Res. Commun., 41, 2013, 293-303.

HIMI, E., NISAR, A., NODA, K.: Colour genes $(R$ and $R c)$ for grain and coleoptile unregulate flavonoid biosynthesis genes in wheat. Genome, 48, 2005, 747-754.

HIMI, E., NODA, K.: Red grain colour gene $(R)$ of wheat is a Myb-type transcription factor. Euphytica, 143, 2005, 239-242.

HODGSON, J.M., CROFT, K.D.: Dietary flavonoids: effects on endothelial function and blood pressure. J. Sci. Food Agric., 86, 2006, 2492-2498.

HOSSEINIAN, F.S., LI, W., BETA, T.: Measurement of anthocyanins and other phytochemicals in purple wheat. Food Chem., 109, 2008, 916-924.

HOLTON, T.A., CORNISH, E.C.: Genetics and biochemistry of anthocyanin biosynthesis. Pl. Cell, 7, 1995, 1071-1083.

HU, C., CAI, Y.-Z., LI, W., CORKE, H., KITTS, D.D.: Anthocyanin characterization and bioactivity assessment of a dark blue grained wheat (Triticum aestivum L. cv. Hedong Wumai) extract. Food Chem., 104, 2007, 955-961.

HURD, E.A.: Inheritance of blue kernel colour in wheat. Can. J. Plant Sci., 39, 1959, $1-8$.

IBANOĞLU, E.: Kinetic study on colour changes in wheat germ due to heat. J. Food Engineering, 51, 2002, 209-213.

IQBAL, S., BHANGERB, M.I., ANWARC, F.: Antioxidant properties and components of bran extracts from selected wheat varieties commercially available in Pakistan. LWT-Food Sci. Technol., 40, 2007, 361-367.

IWASHINA, T.: The structure and distribution of the flavonoids in plants. J. Plant Res., 113, 2000, 287-299.

JACOBS, D.R., STEFFEN, L.M.: Nutrients, foods, and dietary patterns as exposures in research: A framework for food synergy. Am. J. Clin. Nutr., 78, 2003, 508S513S.

KAY, C.D.: Aspects of anthocyanin absorption, metabolism and pharmacokinetics in humans. Nutr. Res. Rev., 19, 2006, 137-146.

KEPPENNE, V.D., BAENZIGER, P.S.: Inheritance of the blue aleurone trait in diverse wheat crosses. Genome, 33, 1990, 525-529.

KHLESTKINA, E.K.: The adaptive role of flavonoids: Emphasis on cereals. Review. Cereal Res. Commun., 41, 2013, 185-198.

KHLESTKINA, E.K., ANTONOVA, E.V., PERSHINA, L.A., SOLOVIEV, A.A., BADAEVA, E.D., BÖRNER, A., SALINA, E.A.: Variability of $R c$ (red coleoptile) alleles in wheat and wheat-alien genetic stock collections. Cereal Res. Commun., $39,2011,465-474$. 
KHLESTKINA, E.K., RÖDER, M.S., BÖRNER, A.: Mapping genes controlling anthocyanin pigmentation on the glume and pericarp in tetraploid beat (Triticum durum L.). Euphytica, 171, 2010, 65-69.

KHLESTKINA, E.K., RÖDER, M.S., PSHENICHNIKOVA, T.A., SIMONOV, A.V., SALINA, E.A., BÖRNER, A.: Genes for anthocyanins pigmentation in wheat: Review and microsatellite-based mapping. In: VERRITY, J.F., ABBINGTON, L.E. (Eds.) Chromosome mapping research development. Nova Science Publishers Inc., New York, 2008, 155-175.

KNIEVEL, D.C., ABDEL-AAL, E.-S.M., RABALSKI, I., NAKAMURA, T., HUCL, P.: Grain color development and the inheritance of high anthocyanin blue aleurone and purple pericarp in spring wheat (Triticum aestivum L.). J. Cereal Sci., 50, 2009, 113-120.

KNOTT, D.R.: The inheritance in wheat of a blue endosperm colour derived from Agropyron elongatum. Can. J. Botany, 36, 1958, 571-574.

KONG, J.-M., CHIA, L.-S., GOH, N.-K., CHIA, T.-F., BROUILLARD, R.: Analysis and biological activities of anthocyanins. Phytochemistry, 64, 2003, 923-933.

LI, W., BETA, T., SUN, S., CORKE, H.: Protein characteristics of Chinese blackgrained wheat. Food Chem., 98, 2006, 463-472.

LI, W., PICKARD, M.D., BETA, T.: Effect of thermal processing on antioxidant properties of purple wheat bran. Food Chem., 104, 2007, 1080-1086.

LI, W., SHAN, F., SUN, S., CORKE, H., BETA, T.: Free radical scavenging properties and phenolic content of Chinese black-grained wheat. J. Agric. Food Chem., 53, 2005, 8533-8536.

LIU, R.H.: Potential synergy of phytochemicals in cancer prevention: mechanism of action. J. Nutr., 134, 2004, 3479S-3485S.

LIU, R.H.: Whole grain phytochemicals and health. J. Cereal Sci., 46, 2007, 207-219.

LIU, M.-S., WANG, F., DONG, Y.-X., ZHANG, X.-S.: Expression analysis of dihydroflavonol 4-reductase genes involved in anthocyanin biosynthesis in purple grains of wheat. J. Integr. Plant Biol., 47, 2005, 1107-1114.

LIU, Q., QIU, Y., BETA, T.: Comparison of antioxidant activities of different colored wheat grains and analysis of phenolic compounds. J. Agric. Food Chem., 58, 2010, 9235-9241.

LIYANA-PATHIRANA, C.M., SHAHIDI, F.: Antioxidant and free radical scavenging activities of whole wheat and milling fractions. Food Chem., 101, 2007, 1151-1157.

MANACH, C., SCALBERT, A., MORAND, C., RÉMÉSY, C., JIMÉNEZ, L.: Polyphenols: Food sources and bioavailability. Am. J. Clin. Nutr., 79, 2004, 727747.

MAZZA, G., BROUILLARD, R.: Recent developments in the stabilization of anthocyanins in food products. Food Chem., 25, 1987, 207-225.

MAZZARACCHIO, P., TOZZI, S., BARBIROLI, G., KINDL, M., PIFFERI, P.G.: Adsorption behaviour of some anthocyanins by wheat gluten and its fractions in acidic conditions. Int. J. Food Sci. Technol., 47, 2012, 390-398.

McINTOSH, R.A., BAKER, E.P.: Inheritance of purple pericarp in wheat. Proceedings of the Linnean Society of New South Wales, Sydney, 92, 1967, 204208. 
McINTOSH, R.A., HART, G.E., DEVOS, K.M., GALE, M.D., ROGERS, W.J.: Catalogue of gene symbols for wheat. In: SLINKARD, A.E. (Ed.) Proceedings of the $9^{\text {th }}$ International Wheat Genetics Symposium. University Extension Press, University of Saskatchewan, Saskatoon, 1998, 235-248.

MIYAMOTO, T., EVERSON, E.H.: Biochemical and physiological studies of wheat seed pigmentation. Agron. J., 50, 1958, 733-734.

PIECH, J., EVANS, L.E.: Monosomic analysis of purple grain colour in hexaploid wheat. Plant Breeding, 82, 1979, 212-217.

PRIOR, L.R., WU, X.: Anthocyanins: Structural characteristics that result in unique metabolic patterns and biological activities. Free Radical Res., 40, 2006, 10141028.

RYAN, K.G., SWINNY, E.E., WINEFIELD, C., MARKHAM, K.R.: Flavonoid and UV photoprotection in Arabidopsis mutants. Z. Naturforschung, 56c, 2001, 745754.

SCHIJLEN, E.G.W.M., RIC DE VOS, C.H., VAN TUNEN, A.J., BOVY, A.G.: Modification of flavonoid biosynthesis in crop plants. Phytochemistry, 65, 2004, 2631-2648.

SIEBENHANDL, S., GRAUSGRUBER, H., PELlEGRINI, N., DEL RIO, D., FOGLIANO, V., PERNICE, R., BERGHOFER, E.: Phytochemical profile on main antioxidant in different fractions of purple and blue wheat, and black barley. J. Agric. Food Chem., 55, 2007, 8541-8547.

TEMPLE, N.J.: Antioxidants and disease: more questions than answers. Nutr. Res., 20, 2000, 449-459.

TERESHCHENKO, O.Y., GORDEEVA, E.I., ARBUZOVA, V.S., BÖRNER, A., KHLESTKINA, E.K.: The D genome carries a gene determining purple grain colour in wheat. Cereal Res. Commun., 40, 2012, 334-341.

TREUTTER, D.: Significance of flavonoids in plant resistance: a review. Environ. Chem. Lett., 4, 2006, 147-157.

VACULOVÁ, K., JIRSA, O., MARTINEK, P., BALOUNOVÁ, M.: Grain quality assessment of non-traditional wheat samples and barley samples with hulless grain. Obilnářské listy, 18, 2010, 71-77.

VAHER, M., MATSO, K., LEVANDI, T., HELMJA, K., KALJURAND, M.: Phenolic compounds and the antioxidant activity of the bran, flour and whole grain of different wheat varieties. Procedia Chem., 2, 2010, 76-82.

VARGA, M., BÁNHIDY, J., CSEUZ, L., MATUZ, J.: The anthocyanin content of blue and purple coloured wheat cultivars and their hybrid generations. Cereal Res. Commun., 41, 2013, 284-292.

WINKEL-SHIRLEY, B.: Flavonoid biosynthesis. A colourful model for genetics, biochemistry, cell biology, and biotechnology. Plant Physiol., 126, 2001, 485-493.

WITTMACK, L.: Die Königliche Landwirtschaftliche Hochschule in Berlin. In: PAREY, P. (Ed.) Festschrift zur Feier des 25jährigen Bestehens. Verlagsbuchhandlung. Paul Parey, Berlin, 1906, 184-245.

ZELLER, F.J., CERMENO, M.C., MILLER, T.E.: Cytological analysis on the distribution and origin of the alien chromosome pair conferring blue aleurone color in several European common wheat (Triticum aestivum L.) strains. TAG, 81, 1991, 551-558. 
ZEVEN, A.C.: Wheats with purple and blue grains: A review. Euphytica, 56, 1991, 243-258.

ŽOFAJOVÁ, A., PŠENÁKOVÁ, I., HAVRLENTOVÁ, M., PILIAROVÁ, M.: Accumulation of total anthocyanins in wheat grain. Agriculture (Pol'nohospodárstvo), 58, 2012, 50-56. 